\title{
Antihyperglycemic Effect of Silkworm Powder, Fibroin and Sericin from Three Thai Silkworm (Bombyx mori Linn.) in Streptozotocin-Induced Diabetic Rats
}

\author{
Surapong Rattana ${ }^{1 *}$, Teeraporn Katisart ${ }^{2}$, Chirapha Butiman ${ }^{3}$, Bunleu Sungthong ${ }^{4}$
}

\section{Surapong Rattana ${ }^{1 *}$, Teeraporn Katisart ${ }^{2}$, Chirapha Butiman ${ }^{3}$, Bunleu Sungthong ${ }^{4}$}

'Department of Biology, Faculty of Science, Mahasarakham University, Maha Sarakham, 44150, THAILAND. 2Department of Biology, Faculty of Science, Mahasarakham University, Maha Sarakham, 44150, THAILAND. ${ }^{3}$ Silk Innovation Center, Mahasarakham University, Maha Sarakham, 44150, THAILAND.

${ }^{4}$ Pharmaceutical Chemistry and Natural Products Research Unit, Faculty of Pharmacy, Mahasarakham University, Maha Sarakham, 44150, THAILAND.

Correspondence

Surapong Rattana, Department of Biology, Faculty of Science, Mahasarakham University, Maha Sarakham, 44150, THAILAND.

Phone number: +6643-754245

E-mail: rattanasurapong@gmail.com

History

- Submission Date: 08-05-2017;

- Review completed: 13-05-2017;

- Accepted Date: 18-05-2017

DOI : 10.5530/pj.2017.4.89

Article Available online

http://www.phcogj.com/v9/i4

\section{Copyright}

(C) 2017 Phcog.Net. This is an openaccess article distributed under the terms of the Creative Commons Attribution 4.0 International license.

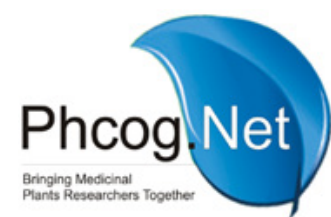

\begin{abstract}
Objective: The present study was aimed to investigate the antihyperglycemic activities of Thai silkworm (Bombyx mori Linn.) powder, fibroin and sericin from three races of Thai silkworm including Nangnoi, Nanglai, and Samrong in streptozotocin-induced diabetic rats. Materials and Methods: All rats were daily and orally administered with silkworm powder $\left(5^{\text {th }}\right.$-instar, $3^{\text {rd }}$-day $)$, fibroin, and sericin at a dose of $250 \mathrm{mg} / \mathrm{kg}$ for 6 weeks. After that, various parameters including body weight, blood glucose, hematological and biochemical parameters were determined. Results: The results revealed that fasting plasma glucose level in $6^{\text {th }}$ week of Nanglai fibroin, Nangnoi fibroin and Nangnoi sericin expressed a better reduction of FPG in diabetic rats compared with diabetic control groups $(p<0.05)$. All hematological parameters of each group were not different within those values ( $p>0.05)$. In case of blood urea nitrogen, creatinine and alkaline phosphatase value showed that some of treated groups was different from diabetic control $(p<0.05)$, while all of treated groups showed different in cholesterol and high density lipoprotein value $(p<0.05)$. Conclusion: Silkworm powders, fibroin and sericin of three races exhibited a therapeutic potential for the reduction plasma glucose level. Treatments of silkworm powder, fibroin and sericin did not have any effect on hematological parameters. Improvement of blood urea nitrogen, creatinine, alkaline phosphatase values and lipid profiles also were also observed in the treatment groups.

Key words: Antihyperglycemic effect, Diabetic rats, Silkworm, Sericin, Fibroin.
\end{abstract}

\section{INTRODUCTION}

The silkworm was domesticated from the wild silk moth, Bombyx mandarina. The domesticated B. mori and the wild $B$. mandarina can still breed and sometimes produce hybrids. ${ }^{1}$ Silkworms have been bred to produce raw silk in China for thousands of years from where it spread to Korea and Japan, and later to India and the West. ${ }^{2}$ Mulberry silkworm (B. mori) has been reared for longtime in many regions of Thailand especially the Northeast. ${ }^{3}$ Reports on the various pharmacological activities of the silkworm have been accumulated such as antioxidant, ${ }^{4}$ anticancer, ${ }^{5}$ antibacterial, ${ }^{6}$ antiviral, ${ }^{7}$ antihypertensive, ${ }^{8}$ and hepatoprotective activities. $^{9}$

Type 2 diabetes is a chronic disease with the mechanisms potentially linked to overweight and obesity. In the year 2014, the prevalence of diabetes was approximately $9 \%$ worldwide. It is particularly caused of disability, premature death and increasing the risk of several chronic diseases such as cardiovascular diseases and renal failure. ${ }^{10}$ Novel therapeutic agents are urgently needed for prevention or treatment. ${ }^{11}$ The use of natural products is considerably one of the choices to prevent the disease. The non-sericin component from silkworm cocoon exhibited an effective in vivo reduction of blood glucose in streptozocininduced diabetes mice. ${ }^{12}$ The antidiabetic activity was possibly related to a-glucosidase inhibitory effect, which had been identified as functions of 1-deoxynojimycin. ${ }^{13}$

In Thailand, there are several varieties of native silkworm races traditionally reared household or as wild types. The difference of races was provided different pharmacological capacities. ${ }^{4}$ Fibroin and sericin from silkworm were generally used as medical biomaterial..$^{14}$ However, there is no report regarding comparison of silkworm powder, fibroin and sericin in in vivo antidiabetic activity. Therefore, the purposes of this study was to compare hypoglycemic activity of silkworm powder, fibroin and sericin from three Thai mulberry silkworm races as well as investigation of the hematological and biochemical parameters in STZ-induced diabetic rats after oral administration of silkworm powder ( $5^{\text {th }}$-instar, $3^{\text {rd }}$-day), fibroin, and sericin.

\section{MATERIALS AND METHODS}

Animals

Male albino Wistar rats, aged 5 to 7 weeks with body weight of 180-200 g were used. ${ }^{15}$ These animals were 
purchased from National Laboratory Animal Center, Mahidol University, Thailand. The rats were fed with a standard diet from National Laboratory Animal Center (Nakhon Prathom, Thailand), and allowed to access to water ad libitum, and acclimated to laboratory conditions for 7 days. All rats were kept in separate cages. One control and one diabetic rat were kept in the same cage. They were provided with feed and water daily for up to 6 weeks until used in the study. All groups were kept in a temperature-controlled room $\left(23 \pm 2{ }^{\circ} \mathrm{C}\right)$, artificially lit from 6.00 to 18.00 hours daily. ${ }^{16}$ The body weights and blood glucose levels of the rats were recorded weekly. The experimental procedure was performed in accordance with the advice of the Institutional Animal Care and Use Ethic Committee, Mahasarakham University, Thailand (Approval license No. 0015/2011).

\section{Induction of diabetes in rats}

The initial blood glucose levels of rats were measured using an AccuCheck active testing kit. The blood was taken from the tail vein. ${ }^{17}$ The bodyweight was also measured to investigate the change in body weight over the six weeks. In order to induce diabetes, streptozotocin (STZ) at dose of $65 \mathrm{mg} / \mathrm{kg}$ bodyweight (b.w.) was injected intraperitoneally to the rats with a single injection. Streptozotocin was freshly dissolved in $20 \mathrm{mM}$ citrate buffer at $\mathrm{pH} 4.5$. The control rats were injected with $20 \mathrm{mM}$ citrate buffer $(\mathrm{pH} 4.5)$ at an equivalent volume to the diabetic group. To avoid the initial hypoglycemic mortality, $2 \%$ sucrose was prepared as drinking water for the STZ-induced diabetic rats for 48 hours. ${ }^{18}$ At the $7^{\text {th }}$ day, the blood glucose of each rat was measured after overnight fasting for 12 hours. The blood glucose level in control rats should be lower than $100 \mathrm{mg} / \mathrm{dL}$. For diabetic groups, the blood glucose level of $126 \mathrm{mg} / \mathrm{dL}$ or higher was recruited into the study.

\section{Preparation of silkworm powder}

Three varieties of Thai mulberry silkworms including Nangnoi (NN), Nanglai (NL), and Samrong (SR) were reared at Silk Innovation Center, Mahasarakham University, Thailand. Identification of silkworm races was performed with regard to the Queen Sirikit Department of Sericulture protocol. The $5^{\text {th }}$ instar, $3^{\text {rd }}$ day silk larvae were used to prepare silkworm powder according to the study of Ryu et al. ${ }^{19}$ suggesting that the highest bioactive compounds were found in this life stage of mulberry silkworm. The silkworms were then freeze-dried and ground in order to obtain fine powders. Silkworm powders were kept in freezer before use.

\section{Preparation of fibroin and sericin}

Silkworms (B. mori), from Nanglai, Nangnoi and Samrong races from Silk Innovation center Mahasarakham University, Thailand, producing yellow cocoons were reared. The extraction and separation of sericin and fibroin were performed in accordance with Martínez-Mora et al..$^{20}$ After the cocoon was formed, pupae were extracted. The empty cocoons were then boiled twice for $45 \mathrm{~min}$ in $0.02 \mathrm{M} \mathrm{Na}_{2} \mathrm{CO}_{3}$. The solution containing sericin fraction was dialyzed for three days in deionized water with a 3,500 molecular weight cut-off membrane. The remaining fibroin was separated from sericin solution by filtration. To obtain a high purity fibroin, the fibroin was rinsed thoroughly with large amount of water to clean the remaining sericin proteins. The fibroin was then dried at room temperature for $72 \mathrm{~h}$ and dissolved in $9.3 \mathrm{M} \mathrm{LiBr}$ for 3 hours at $60^{\circ} \mathrm{C}$ to generate a $20 \% \mathrm{w} / \mathrm{v}$ solution. Then, the solution was further dialyzed in distilled water for 3 days and the resultant solution was freeze-dried and stored at $4^{\circ} \mathrm{C}$. To obtain the desired concentration, the purified silk fibroin was dissolved in deionized water. According, the method proposed by Martínez-Mora et al. ${ }^{20}$ the purity of sericin and fibroin were approximately $99 \%$.

\section{Experimental designs}

The animals were randomly divided into the following twelve experimental groups with 6 animals in each: group 1 was normal control rats treated orally with distilled water; group 2 was diabetic control rats treated orally with distilled water; group 3 was treated with glibenclamide $(0.25 \mathrm{mg} / \mathrm{kg}$ b.w.); group 4-6 were diabetic rats treated orally with silkworm powder $(250 \mathrm{mg} / \mathrm{kg}$ b.w.) of Nanglai (NL-W), Nangnoi (NN-W), and Samrong (SR-W) races, respectively; group 7-9 were diabetic rats treated orally with fibroin (250 mg/kg b.w.) of Nanglai (NL-F), Nangnoi (NN-F), and Samrong (SR-F) races, respectively; group 10-12 were diabetic rats treated orally with sericin (250 mg/kg b.w.) of Nanglai (NL-S), Nangnoi (NN-S), and Samrong (SR-S) races, respectively. Silkworm powder and glibenclamide were suspended in $1 \%$ carboxymethyl cellulose and orally administered using orogastric tube dialy at 10 a.m. for 6 weeks.

\section{Effect of silkworm powder, fibroin, and sericin on body weight}

The normal and STZ-induced diabetic rats were weighed weekly before silkworm or water administration to investigate the change of body weight during 6 weeks of the experiment.

\section{Effect of silkworm powder, fibroin, and sericin on fasting plasma glucose levels}

The normal and STZ-induced diabetic rats were fasted for 12 hours. Then, the blood samples were collected from the tail vein of each rat and measured plasma glucose by using Accu-check Advantage II (Roche, Germany). FPG were measured every 2 weeks in each experimental group.

\section{Effect of silkworm powder, fibroin, and sericin on hematological and biochemical parameters}

Sixth weeks after the experiments, all rats were fasted for 12 hours. They were sacrificed by cervical dislocation technique. Then, blood samples obtained from cardiac puncture ${ }^{21}$ were analyzed for hematological values including red blood cell counts (RBC), white blood cell counts (WBC), $\%$ of hematocrit (Hct) and $\mathrm{g} \%$ of hemoglobin $(\mathrm{Hb})$, and biochemical parameters including total cholesterol (CHO), triglyceride (TG), high-density lipoprotein cholesterol (HDL), low-density lipoprotein cholesterol (LDL), blood urea nitrogen (BUN), creatinine, and alkaline phosphatase (ALP) by an automatic blood chemical analyzer (BT 2000 plus, Germany).

\section{Statistical analysis}

All data were expressed as mean \pm standard error of mean (S.E.M.). Statistical analysis was carried out using F-test (One-way ANOVA) followed by Scheffe's test using SPSS version 15 . The statistical significant difference was obtained at a $p$-value less than 0.05 .

\section{RESULTS AND DISCUSSION}

\section{Effect of silkworm powder, fibroin, and sericin on body weight}

Silkworm powder from three races of Thai silkworm (NL, NN, and SR) increased the body weight of rats in all treatments throughout six weeks of the experiments. However, diabetic control rats have slightly decrease body weight (figure 1). Interestingly, diabetic rats treated with glibenclamide have remarkably increased body weight throughout six weeks of the experiment, almost equivalent to those from normal control rats, suggesting the efficacy of glibenclamide in recovering the severity of the disease. On the other words, diabetic rats treated with the three races of silkworm powder, fibroin and sericin tended to have slightly increased 


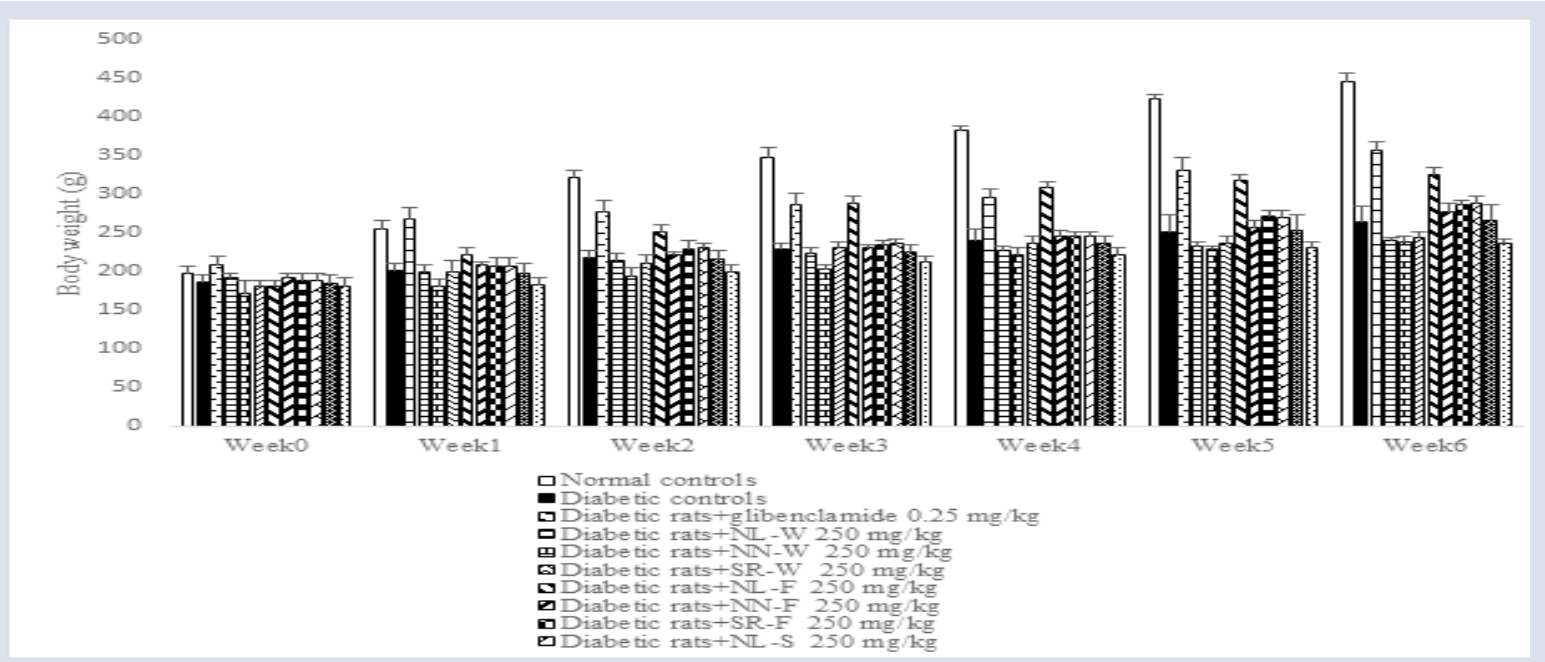

Figure 1: Body weight of normal control, diabetic control, and diabetic rats treated with glibenclamide, silkworm powder, fibroin and sericin of three silkworm races.

body weight. The body weight loss could be from glycolysis, lipid and protein metabolism in muscle in order to get sufficient energy, which causes by insulin-mediated glucose uptake resistance of peripheral tissues to utilize glucose as a primary energy source. ${ }^{22}$ For this reason, diabetic rats showed lower body weight comparing with normal rats.

\section{Effect of silkworm powder, fibroin, and sericin on fasting plasma glucose levels}

As shown in Table 1, lowering FPG effect in normal rats and diabetic rats which treated with silkworm powder, fibroin and sericin of three varieties at dose of $250 \mathrm{mg} / \mathrm{kg}$ b.w. and glibenclamide were observed for 6 weeks. The finding presented significantly decreased FPG in some week. Decreasing of FPG in those silkworms compared to normal rats and diabetic rats started from initial time were almost equal to glibenclamide $(0.25 \mathrm{mg} / \mathrm{kg}$ b.w. $)$ treatment group; particularly at the second week for Nanglai fibroin and Nangnoi fibroin treatment had better reduction of
FPG than glibenclamide and others, whereas Nanglai fibroin, Nangnoi fibroin, Nangnoi sericin and glibenclamide groups appeared decreasing FPG at sixth week. The antihyperglycemic activities of silkworm powders were previously explained by Kiyotaka et al. ${ }^{23}$ that silkworm powder has high 1-deoxynojirimycin (DNJ) contents about $0.3 \% \mathrm{w} / \mathrm{w}$. DNJ was a well-known in alpha-glucosidase inhibitory activity. ${ }^{24}$ In addition, other chemical compositions in silkworm powder such as beta-sitosterol and stigmasterol has been reported on antidiabetic activity in STZ-induced diabetic rat. ${ }^{25-26}$ Regarding other compounds, the silk protein (1:1 of fibroin and sericin) fed mice showed significantly lower insulin level and higher glycogen concentration than the high fat-fed mice. ${ }^{27}$ Previous studies on silk protein pointed out that the soluble fibroin could decrease blood glucose and increase insulin concentrations in mice. ${ }^{28-29}$ Similar effect had been observed by Okazaki et al. ${ }^{30}$ that dietary feeding of silk sericin decreased in plasma glucose and increased insulin secretion after an interperitoneal glucose injection in high fat-fed rats.

Table 1: FPG of normal control, diabetic control, diabetic rats treated with glibenclamide, silkworm powder, fibroin and sericin of three silkworm races.

\begin{tabular}{|c|c|c|c|c|}
\hline \multirow[b]{2}{*}{ treatments } & \multicolumn{4}{|c|}{ FPG (mg/dL) } \\
\hline & week0 & week2 & week4 & week6 \\
\hline Normal control & $79.16 \pm 5.18^{*}$ & $93.50 \pm 6.11^{*}$ & $98.50 \pm 5.81^{*}$ & $107.33 \pm 5.38^{*}$ \\
\hline Diabetic control & $200.03 \pm 16.91$ & $492.33 \pm 41.69$ & $528.33 \pm 44.75$ & $519.50 \pm 43.91$ \\
\hline Diabetic rats+glibenclamide $0.25 \mathrm{mg} / \mathrm{kg}$ & $219.17 \pm 9.64$ & $232.50 \pm 10.16$ & $115.50 \pm 5.17^{*}$ & $79.33 \pm 3.48^{*}$ \\
\hline Diabetic rats+NL-W $250 \mathrm{mg} / \mathrm{kg}$ & $246.32 \pm 10.31$ & $239.13 \pm 21.68$ & $387.61 \pm 21.35$ & $388.62 \pm 16.71$ \\
\hline Diabetic rats $+\mathrm{NN}-\mathrm{W} 250 \mathrm{mg} / \mathrm{kg}$ & $234.50 \pm 9.53$ & $238.90 \pm 17.11$ & $305.50 \pm 12.78$ & $388.51 \pm 20.45$ \\
\hline Diabetic rats+SR-W $250 \mathrm{mg} / \mathrm{kg}$ & $274.17 \pm 12.19$ & $332.54 \pm 19.53$ & $404.31 \pm 10.17$ & $476.35 \pm 21.19$ \\
\hline Diabetic rats+NL-F $250 \mathrm{mg} / \mathrm{kg}$ & $164.50 \pm 10.08$ & $98.50 \pm 6.20^{*}$ & $79.50 \pm 4.85^{*}$ & $81.50 \pm 5.12^{*}$ \\
\hline Diabetic rats+NN-F $250 \mathrm{mg} / \mathrm{kg}$ & $131.16 \pm 5.13$ & $79.33 \pm 4.40^{*}$ & $65.50 \pm 4.07^{*}$ & $89.67 \pm 4.67^{*}$ \\
\hline Diabetic rats+SR-F $250 \mathrm{mg} / \mathrm{kg}$ & $132.50 \pm 8.75$ & $198.50 \pm 19.38$ & $416.66 \pm 15.47$ & $271.66 \pm 21.19$ \\
\hline Diabetic rats+NL-S $250 \mathrm{mg} / \mathrm{kg}$ & $195.02 \pm 15.54$ & $209.66 \pm 16.70$ & $342.33 \pm 27.33$ & $210.50 \pm 16.97$ \\
\hline Diabetic rats+NN-S $250 \mathrm{mg} / \mathrm{kg}$ & $158.33 \pm 12.49$ & $162.50 \pm 4.96$ & $102.50 \pm 8.12^{*}$ & $103.66 \pm 8.14^{*}$ \\
\hline Diabetic rats+SR-S $250 \mathrm{mg} / \mathrm{kg}$ & $195.03 \pm 14.54$ & $360.66 \pm 28.77$ & $492.50 \pm 39.39$ & $460.33 \pm 36.73$ \\
\hline
\end{tabular}

Data are shown as mean \pm S.E.M., $(\mathrm{n}=6)$. * showed significantly difference from diabetes control group $(p<0.05)$. 
Table 2: Hematological parameters of normal control, diabetic control, diabetic rats treated with glibenclamide, silkworm powder, fibroin and sericin of three silkworm races after 6 weeks treatment.

\begin{tabular}{|c|c|c|c|c|c|}
\hline treatments & $\begin{array}{c}\mathrm{Hb} \\
(\mathrm{g} \%)\end{array}$ & $\begin{array}{l}\text { Hct } \\
(\%) \\
\end{array}$ & $\begin{array}{c}\text { RBC } \\
\left(10^{6} \text { cells } / \mathrm{mL}\right)\end{array}$ & $\begin{array}{c}\text { WBC } \\
\left(10^{3} \text { cells } / \mathrm{mL}\right)\end{array}$ & $\begin{array}{c}\text { Platelet } \\
\left(10^{5} \text { cells } / \mathrm{mL}\right)\end{array}$ \\
\hline Normal control & $16.16 \pm 1.04$ & $48.66 \pm 1.52$ & $8.26 \pm 0.21$ & $4.63 \pm 0.50$ & $7.29 \pm 0.33$ \\
\hline Diabetic rats+glibenclamide $0.25 \mathrm{mg} / \mathrm{kg}$ & $15.96 \pm 0.55$ & $47.33 \pm 1.52$ & $8.10 \pm 0.75$ & $5.40 \pm 1.83$ & $7.21 \pm 1.70$ \\
\hline Diabetic rats+NL-W 250 mg/kg & $15.56 \pm 1.72$ & $47.33 \pm 4.50$ & $8.50 \pm 0.95$ & $5.63 \pm 0.40$ & $6.66 \pm 0.08$ \\
\hline Diabetic rats+NN-W $250 \mathrm{mg} / \mathrm{kg}$ & $16.16 \pm 1.05$ & $48.00 \pm 3.60$ & $8.56 \pm 1.09$ & $6.30 \pm 1.41$ & $6.59 \pm 0.49$ \\
\hline Diabetic rats+NL-F $250 \mathrm{mg} / \mathrm{kg}$ & $15.30 \pm 0.95$ & $45.67 \pm 3.51$ & $8.20 \pm 0.99$ & $3.93 \pm 0.57$ & $6.54 \pm 0.14$ \\
\hline Diabetic rats+NN-F $250 \mathrm{mg} / \mathrm{kg}$ & $17.73 \pm 1.36$ & $52.66 \pm 4.04$ & $8.10 \pm 0.75$ & $4.33 \pm 1.33$ & $6.79 \pm 0.94$ \\
\hline Diabetic rats+SR-F 250 mg/kg & $17.96 \pm 1.80$ & $53.66 \pm 5.03$ & $9.40 \pm 0.98$ & $4.33 \pm 2.50$ & $6.60 \pm 0.65$ \\
\hline Diabetic rats+NL-S $250 \mathrm{mg} / \mathrm{kg}$ & $15.73 \pm 2.43$ & $47.33 \pm 6.65$ & $8.33 \pm 0.86$ & $4.60 \pm 1.90$ & $6.82 \pm 0.97$ \\
\hline Diabetic rats+NN-S $250 \mathrm{mg} / \mathrm{kg}$ & $15.56 \pm 2.30$ & $46.33 \pm 6.50$ & $7.43 \pm 1.04$ & $4.66 \pm 2.04$ & $7.30 \pm 0.39$ \\
\hline
\end{tabular}

Data are shown as mean \pm S.E.M. $(n=6)$.

Table 3: Blood chemical parameters (BUN, creatinine and ALP) of normal control, diabetic control, diabetic rats treated with glibenclamide, silkworm powder, fibroin and sericin of three silkworm races after 6 weeks treatment.

\begin{tabular}{lccc}
\hline \multicolumn{1}{c}{ Treatment } & BUN $(\mathrm{mg} / \mathrm{dL})$ & Creatinine $(\mathrm{mg} / \mathrm{dL})$ & ALP $($ IU/L) \\
\hline Normal control & $29.96 \pm 1.01^{*}$ & $0.90 \pm 0.10^{*}$ & $91.33 \pm 6.02^{*}$ \\
Diabetic control & $51.36 \pm 2.56$ & $1.36 \pm 0.30$ & $324.33 \pm 46.23$ \\
Diabetic rats+glibenclamide $0.25 \mathrm{mg} / \mathrm{kg}$ & $39.56 \pm 3.91^{*}$ & $1.06 \pm 0.11^{*}$ & $93.66 \pm 9.21^{*}$ \\
Diabetic rats+NL-W $250 \mathrm{mg} / \mathrm{kg}$ & $38.66 \pm 3.74^{*}$ & $1.10 \pm 0.20^{*}$ & $247.33 \pm 26.02$ \\
Diabetic rats+NN-W $250 \mathrm{mg} / \mathrm{kg}$ & $42.33 \pm 2.44^{*}$ & $1.10 \pm 0.10^{*}$ & $314.33 \pm 49.03$ \\
Diabetic rats+SR-W $250 \mathrm{mg} / \mathrm{kg}$ & $49.46 \pm 6.50$ & $1.33 \pm 0.15$ & $169.00 \pm 27.07^{*}$ \\
Diabetic rats+NL-F $250 \mathrm{mg} / \mathrm{kg}$ & $40.73 \pm 5.77^{*}$ & $1.16 \pm 0.15^{*}$ & $77.33 \pm 4.72^{*}$ \\
Diabetic rats+NN-F $250 \mathrm{mg} / \mathrm{kg}$ & $39.63 \pm 5.52^{*}$ & $1.00 \pm 0.10^{*}$ & $126.00 \pm 19.97^{*}$ \\
Diabetic rats+SR-F $250 \mathrm{mg} / \mathrm{kg}$ & $39.70 \pm 4.34^{*}$ & $1.10 \pm 0.10^{*}$ & $192.67 \pm 29.70^{*}$ \\
Diabetic rats+NL-S $250 \mathrm{mg} / \mathrm{kg}$ & $47.36 \pm 6.83$ & $1.20 \pm 0.30$ & $92.00 \pm 2.64^{*}$ \\
Diabetic rats+NN-S $250 \mathrm{mg} / \mathrm{kg}$ & $37.96 \pm 3.80^{*}$ & $1.23 \pm 0.11$ & $172.66 \pm 35.55^{*}$ \\
Diabetic rats+SR-S $250 \mathrm{mg} / \mathrm{kg}$ & $40.43 \pm 5.45^{*}$ & $1.30 \pm 0.31$ & $212.66 \pm 13.05^{*}$ \\
\hline
\end{tabular}

Data are shown as mean \pm S.E.M. $(\mathrm{n}=6)$. ${ }^{*}$ showed significantly difference from diabetic controls group $(p<0.05)$.

Table 4: Lipid profile (CHO, TG, HDL and LDL) of normal control, diabetic control, diabetic rats treated with glibenclamide, silkworm powder, fibroin and sericin of three silkworm races after 6 weeks treatment.

\begin{tabular}{lcccc}
\hline & \multicolumn{3}{c}{ Lipid profiles (mg/dL) } \\
\cline { 2 - 5 } \multicolumn{1}{c}{ Treatment } & CHO & TG & HDL & LDL \\
\hline Normal control & $91.33 \pm 6.02^{*}$ & $119.33 \pm 14.57^{*}$ & $56.66 \pm 4.50^{*}$ & $57.00 \pm 5.56^{*}$ \\
Diabetic control & $292.00 \pm 58.59$ & $285.66 \pm 11.59$ & $24.33 \pm 4.50$ & $113.66 \pm 3.05$ \\
Diabetic rats+glibenclamide $0.25 \mathrm{mg} / \mathrm{kg}$ & $125.66 \pm 12.01^{*}$ & $151.00 \pm 25.35^{*}$ & $33.33 \pm 3.51^{*}$ & $76.33 \pm 3.05^{*}$ \\
Diabetic rats+NL-W 250 mg/kg & $183.66 \pm 13.31^{*}$ & $224.33 \pm 23.75$ & $31.33 \pm 5.03^{*}$ & $77.00 \pm 9.16^{*}$ \\
Diabetic rats+NN-W 250 mg/kg & $185.66 \pm 40.41^{*}$ & $156.66 \pm 7.09^{*}$ & $39.33 \pm 2.51^{*}$ & $80.33 \pm 8.62^{*}$ \\
Diabetic rats+SR-W 250 mg/kg & $172.66 \pm 12.74^{*}$ & $183.33 \pm 8.50^{*}$ & $37.66 \pm 2.51^{*}$ & $107.00 \pm 5.56$ \\
Diabetic rats+NL-F 250 mg/kg & $115.66 \pm 23.79^{*}$ & $175.33 \pm 22.81^{*}$ & $33.00 \pm 3.46^{*}$ & $74.33 \pm 7.50^{*}$ \\
Diabetic rats+NN-F 250 mg/kg & $129.00 \pm 15.52^{*}$ & $145.33 \pm 11.01^{*}$ & $32.66 \pm 5.50^{*}$ & $81.00 \pm 4.00^{*}$ \\
Diabetic rats+SR-F 250 mg/kg & $148.00 \pm 35.79^{*}$ & $118.33 \pm 15.17^{*}$ & $32.66 \pm 3.21^{*}$ & $78.00 \pm 3.52^{*}$ \\
Diabetic rats+NL-S 250 mg/kg & $191.66 \pm 16.25^{*}$ & $181.00 \pm 48.38^{*}$ & $41.33 \pm 8.32^{*}$ & $104.00 \pm 8.18$ \\
Diabetic rats+NN-S 250 mg/kg & $150.00 \pm 32.14^{*}$ & $138.33 \pm 37.89^{*}$ & $35.00 \pm 5.56^{*}$ & $88.00 \pm 9.97^{*}$ \\
Diabetic rats+SR-S 250 mg/kg & $163.66 \pm 18.55^{*}$ & $215.00 \pm 43.00$ & $37.66 \pm 1.15^{*}$ & $102.33 \pm 8.08$ \\
\hline
\end{tabular}

Data are shown as mean \pm S.E.M. $(n=6)$. " showed significantly difference from diabetic control group $(p<0.05)$. 


\section{Effect of silkworm powder, fibroin, and sericin on} hematological data

Hematological parameters in rats from all treatments were investigated. These found that hemaglobin ( $\mathrm{Hb})$, red blood cell count (RBC), white blood cell count (WBC), and platelets values were not significantly difference $(p>0.05)$ within those groups (Table 2$)$. This study was the first report regarding toxicity of silkworm powder, fibroin and sericin on hematological parameters. In silkworm powder, the nutritional value of silkworm powder $\left(5^{\text {th }}\right.$ instar and $3^{\text {rd }}$ day) consisted of protein containing 16-18 amino acid about $60-70 \% .^{14,31}$ The content of silkworm powder is not different from normal food. Therefore, changes in hematological parameters were not significant difference. Moreover, Kaskoos et al. ${ }^{32}$ reported that the chemical compositions of the silkworm such as polyphenols did not effect on hematological parameters as well.

\section{Effect of silkworm powder, fibroin, and sericin on renal and hepatic functions}

The effects of all treatment groups on renal functions were expressed as BUN and creatinine values (Table 3 ). The most treatment groups showed that BUN values were significantly lower comparing with diabetic controls group $(p<0.05)$. However, diabetic rats treated with Samrong silkworm and Nanglai silkworm were not significant difference from diabetic controls group $(p>0.05)$. Regarding creatinine values, diabetic rats treated with Samrong silkworm, Nanglai sericin, Nangnoi sericin and Samrong sericin were not significant difference from diabetic controls group ( $p>0.05)$. However, other experimental groups were significantly different from diabetic control group $(p<0.05)$. The previous study showed that silkworm containing quercetin improved BUN and creatinine values in rat. ${ }^{33}$

The effects of silkworm powder, fibroin and sericin on hepatic function were expressed as ALP (Table 3). The diabetic rats treated with Nanglai silkworm and Nangnoi silkworm were not significant different in ALP from diabetic controls group ( $p>0.05)$. However, other groups showed the lower ALP value compared with diabetic controls group $(p<0.05)$.

\section{Effect of silkworm powder, fibroin, and sericin on lipid profiles}

The effect of all treatment groups on lipid profiles (CHO, TG, HDL and LDL) have been shown in Table 4. CHO and HDL values in all experimental groups were significant different from diabetic control group $(p<0.05)$, while TG values in the most of experimental groups were significant different from diabetic control group $(p<0.05)$. However, diabetic rats treated with Nanglai silkworm and Samrong sericin were not significant different from diabetic control group $(p>0.05)$. LDL values in diabetic rats treated with Samrong silkworm, Nanglai sericin and Samrong ssericin were not significantly different from diabetic control group ( $p>0.05)$, while other groups were significant different $(p<0.05)$. It can be explained that the decreasing of total cholesterol was possible from silk protein. ${ }^{34}$ This study confirmed that silkworm, fibroin and sericin from Thai races had reduced complications by improving blood chemical parameters and blood lipid profiles in streptozotocin-induced diabetic rats.

\section{CONCLUSION}

Silkworm powders, fibroin and sericin of three races exhibited a therapeutic potential for the reduction plasma glucose level. Treatments of silkworm powder, fibroin and sericin did not have any effect on hematological parameters. Improvement of BUN, creatinine, ALP and lipid profiles also were also observed in the treatment groups.

\section{ACKNOWLEDGEMENT}

The authors would like to thank the National Research Council of Thailand (NRCT) for the financial support.

\section{CONFLICT OF INTEREST}

Authors declare no conflict of interest.

\section{ABBREVIATIONS USED}

FPG: fasting blood glucose level; Hb: hemoglobin; Hct: hematocrit; RBC: red blood cell; WBC: white blood cell; BUN: blood urea nitrogen; ALP: alkalinephosphatase; CHO: cholesterol; TG: triglyceride; HDL: high density lipoprotein; LDL: Low density lipoprotein; NL: Nanglai race; NN: Nangnoi race; SR: Samrong race; W: silkworm; F: fibroin; S: sericin.

\section{REFERENCES}

1. Ohnishi A, Kaji M, Hashimoto K, Matsumoto S. Screening for the genes involved in bombykol biosynthesis: identification and functional characterization of Bombyx mori Acyl carrier protein. Frontiers Endocrinol (Lausanne) 2011;2:doi:10.3389/fendo. 2011.00092

2. Arunkumar KP, Metta M, Nagaraju J. Molecular phylogeny of silkmoths reveals the origin of domesticated silkmoth, Bombyx mori from Chinese Bombyx mandarina and paternal inheritance of Antheraea proylei mitochondrial DNA. Mol Phylogenet Evol 2006;40(2):419-27. https://doi.org/10.1016/j. ympev.2006.02.023; PMid:16644243

3. Sumranpath K, Aungsuratana A, Auttathom T, Poramacom N. Existing condition of commercial sericulture production in Northeastern Thailand. Kasetsart $J$ (Social Sciences). 2015;36:155-64

4. Manosroi A, Boonpisuttinant K, Winitchai S, Manosroi W, Manosroi J. Free radical scavenging and tyrosinase inhibition activity of oils and sericin extracted from Thai native silkworms (Bombyx mori). Pharm Biol. 2010;48(8):855-60. https://doi.org/10.3109/13880200903300212; PMid:20673171.

5. Hu D, Liu Q, Cui H, Wang H, Han D, Xu H. Effects of amino acids from selenium rich silkworm pupas on human hepatoma cells. Life Sciences. 2005;77(17):2098-110. https://doi.org/10.1016/j.Ifs.2005.02.017; PMid:15978626.

6. Li BC, Zhang SQ, Dan WB, Chen YQ, Cao P. Expression in Escherichia coli and purification of bioactive antibacterial peptide ABP-CM4 from the Chinese silk worm, Bombyx mori. Biotechnol Lett. 2007:29(7):1031-6. https://doi. org/10.1007/s10529-007-9351-4; PMid:17375264

7. Jacob JR, Mansfield K, You JE, Tennant BC, Kim YH. Natural iminosugar derivatives of 1-deoxynojirimycin inhibit glycosylation of hepatitis viral envelope proteins. J Microbiol 2007;45(5):431-40. PMid:17978803.

8. Quan GX, Mita K, Okano K, Shimada T, Ugajin N, Xia Z, et al. Isolation and expression of the ecdysteroid-inducible angiotensin-converting enzyme-related gene in wing discs of Bombyx mori. Insect Biochem Mol Biol. 2001;31(1):97-103. https://doi.org/10.1016/S0965-1748(00)00112-0.

9. Raghavendra R, Neelagund S, Kuluvar G, Bhanuprakash V, Revanaiah Y. Protective effect of partially purified $35 \mathrm{kDa}$ protein from silk worm (Bombyx morı) fecal matter against carbon tetrachloride induced hepatotoxicity and in vitro anti-viral properties. Pharm Biol. 2010;48(12):1426-31. https://doi.org/10.3109/13880209. 2010.489565 ; PMid:20738178.

10. World Health Organization. Global Status Report on non-communicable diseases 2014. WHO press, Geneva, Switzerland. 2014;79-94.

11. Leiherer A, Mundlein A, Drexel $H$. Phytochemicals and their impact on adipose tissue inflammation and diabetes. Vasc Pharmacol. 2012;58(1):3-20. PMid:22982056.

12. Wang HY, Wang YJ, Zhou LX, Zhu L, Zhang YQ. Isolation and bioactivities of a non-sericin component from cocoon shell silk sericin of the silkworm Bombyx mori. Food Funct. 2012;3(2):150-8. https://doi.org/10.1039/C1F010148J; PMid:22101964

13. Yatsunami K, Murata K, Kamei T. 1-Deoxynojirimycin content and alpha-glucosidase inhibitory activity and heat stability of 1-deoxynojirimycin in silkworm powder. Food Nutr Sci. 2011;2(02):87-9. https://doi.org/10.4236/fns.2011.22011.

14. Mondal M, Trivedy K, Kumar NS. The silk proteins, sericin and fibroin in silkworm, Bombyx mori Linn, - a review. Caspian J Environ. Sci 2007;5(2):63-76.

15. Dandapat S, Sinha MP, Kumar M, JaggiY. Heppatoprotective efficacy of medicinal mushroom Pleurotus tuberregium. Env Exp Biol. 2015;13(3):103-8.

16. Kiran GR, Raju AB. Antiobesity effect of Plytolacca berry in rats. Env Exp Biol. 2014;12:95-9.

17. Pranakhon R, Pannangpetch $P$, Aromdee C. Antihyperglycemic activity of agarwood leaf extracts in STZ-induced diabetic rats and glucose uptake enhancement activity in rat adipocytes. Songklanakarin J Sci Technol. 2011;33(4):405-10. 
18. Manok S, Sungthong B, Sato H, Sato VH. Hypoglycemia and antioxidant activities of the water extract of Aquilaria crassna leaves in Streptozotocin-Nicotinamide induce type 2 diabetic mice. Nat Prod Commun. 2016;11:757-61.

19. Ryu KS, Ahn MY, Lee HS, Kim IS, Kim JW, Kim SH, et al. The tonic effect of the extract from male silkworm (Bombyx mori L.) pupae on rats. Int J Indust Entomol. 2002;5(1):123-6.

20. Martınez-Mora C, Mrowiec A, Garci'a-Vizcaı́no EM, Alcaraz A, Cenis JL, Nicolás FJ. Fibroin and sericin from Bombyx mori silk stimulate cell migration through upregulation and phosphorylation of c-Jun. PLoS ONE 2012;7:e42271. doi:10.1371/journal.pone. 0042271.

21. Bhushan B, Punde S, Saxena N, Saxena PN. Serum biochemical responses under stress of cypermenthrin in albino rat. Env Exp Biol. 2013;11: 81-9.

22. Ravi K, Ramachandran B, Subramanian. Protective effect of Eugenia jambolana seed kernal on tissue antioxidants in streptozotocin induced diabetic rats. Biol Pharm Bull. 2004;27(8):1212-7. https://doi.org/10.1248/bpb.27.1212 PMid:15305024.

23. Kiyotaka N, Kenta O, Ohki H, Toshiyuki K, Teruo M, Masatoshi H. Determination of iminosugars in mulberry leaves and silkworm using hydrophilic interaction chromatography-tandem mass spectrometry. Anal Biochem. 2010;404(2):217-22 https://doi.org/10.1016/j.ab.2010.05.007; PMid:20470744

24. Li YG, Ji DF, Zhong S, Lin TB, Lv ZQ, Hu GY, et al. 1-Deoxynojirimycin inhibits glucose absorption and accelerates glucose metabolism in streptozotocininduced diabetic mice. Sci Rep. 2013;3:1377.doi:10.1038/srep01377. https://doi. org/10.1038/srep01377.

25. Igarashi F, Hikiba J, Ogihara MH, Nakaoka T, Suzuki M, Kataoka HA. Highly specific and sensitive quantification analysis of the sterols in silkworm larvae by high performance liquid chromatography-atmospheric pressure chemical ionizationtandem mass spectrometry. Anal Biochem. 2011:419(2):123-32. https://doi org/10.1016/j.ab.2011.08.046; PMid:21925474
26. Gupta R, Sharma AK, Dobhal MP, Sharma MC, Gupta RS. Antidiabetic and antioxidant potential of $\beta$-sitosterol in streptozotocin-induced experimental hyperglycemia. J Diabetes. 2011;3(1):29-37. https://doi.org/10.1111/j.1753-0407. 2010.00107.x; PMid:21143769

27. Seo CW, Um IC, Rico CW, Kang MY. Antioxidative and hypoglycemic effects of silk fibroin/sericin mixtures in high fat-fed mice. Int J Indus Entomol. 2011; 23(1):115-22. https://doi.org/10.7852/ijie.2011.23.1.115.

28. Hyu CK, Kim IY, Frost SC. Soluble fibroin enhances insulin sensitivity and glucose metabolism in 3T3-L1 adipocytes. J Nutr. 2004;134(2):3257-63.

29. Nahm JH, Oh YS. A study on the pharmacological effect of silk fibroin. RDA J Agric Sci. 1995;37(37):145-57.

30. Okazaki Y, Kakehi S, Xu Y, Tsujimoto K, Sasaki M, Ogawa H, et al. Consumption of sericin reduces serum lipids, ameliorates glucose tolerance and elevates serum adiponectin in rats fed a high-fat diet. Biosci Biotechnol Biochem. 2010;74(8):1534-8. https://doi.org/10.1271/bbb.100065; PMid:20699593.

31. Trivedy K, Ramesh M, Kumar SN, Qadri SMH. Major nutritional component of silkworm (Bombyx mori) powder. Indian J Seri. 2010;49:210-4.

32. Kaskoos RA, Ali M, Naquvi KJ. Phytochemical investigation of the silk cocoons in Bombyx mori Linn. IRJP. 2012;3:180-3.

33. Nazmi AS, Ahmad SJ, Pillai KK, Aktar M, Ahmad A, Najmi AK. Protective effects of Bombyx mori, quercetin and benazepril against doxorubicin induced cardiotoxicity and nephrotoxicity. J Saudi Chem Soc. 2013; http://dx.doi.org/10.1016/j. jscs.2013.04.001.

34. Seo CW, Um IC, Rico CW, Kang MY. Antihyperlipidemic and body fat-lowering effects of silk proteins with different fibroin/sericin compositions in mice fed with high fat diet. J Agri Food Chem. 2011;59(8):4192-7. https://doi.org/10.1021/ jf104812g; PMid:21384872.

\section{GRAPHICAL ABSTRACT}
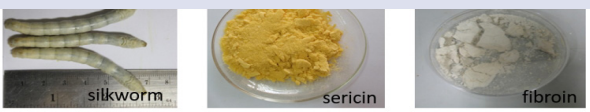

$50 \mathrm{mg} / \mathrm{kg}, 6$ wee

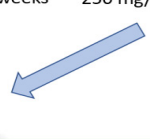

$\mathrm{mg} / \mathrm{kg}, 6$ weeks
$250 \mathrm{mg} / \mathrm{kg}$, 6 week

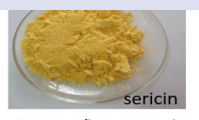

$>$

2

Antihyperglycemic Effect in

Streptozotocin-Induced Diabetic Rats

\section{HIGHLIGHTS OF PAPER}

- $\quad$ Silkworm (Bombyx mori L.) have been employed in traditional medicine in treatment for diabetes mellitus.

- Silkworm powder, fibroin and sericin, derived from silkworm have been used.

- $\quad$ The present study was aimed to investigate the antihyperglycemic activities of Thai silkworm (Bombyx mori L.) powder, fibroin and sericin of three races

- $\quad$ Silkworm powders, fibroin and sericin of three races exhibited a therapeutic potential for the reduction plasma glucose level. According hematological parameters, they expressed no effect on hematological parameters. Improvement of BUN, creatinine, ALP and lipid profiles also were also observed in the treatment groups

\section{ABOUT AUTHORS}

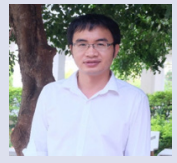

Mr. Surapong Rattana: Obtained his M.Sc. degree in 2012 from Faculty of Pharmacy, Mahasarakham University, Thailand. Currently, He is Ph.D candidate in Biology major, Faculty of Science, Mahasarakham University, Thailand. Mr. Rattana is working on various aspect of medicinal plant related separation and isolation of both pure active compound and crude drug from herb for toxicity and biological activities test to finding therapeutic valuable of medicinal plant.

Cite this article : Rattana S, Katisart T, Butiman C, Sungthong B. Antihyperglycemic Effect of Silkworm Powder, Fibroin and Sericin from Three Thai Silkworm (Bombyx mori Linn.) in Streptozotocin-Induced Diabetic Rats. Pharmacog J. 2017;9(4):559-64. 